https://doi.org/10.31470/2706-7904-2021-16-64-68

\title{
СИНОНІМИ В ЛЕКСИКОНІ ДІТЕЙ ДОШКІЛЬНОГО ВІКУ
}

Synonyms in the Lexicon of Preschool Children

\author{
Svitlana Demianenko \\ Ph.D. in Pedagogy, Associate Professor \\ Hryhorii Skovoroda University in Pereiaslav (Ukraine) \\ demianenko.lana@gmail.com \\ https://orcid.org/0000-0002-0161-7024
}

\begin{abstract}
The article is devoted to the study of the vocabulary of older preschool children, which outlines the linguistic analysis of synonymous words in the speech of older preschool children. The paper outlines the peculiarities of the use of synonyms in connection with the ability of children to find in reality important facts and signs based on similarities and differences and the meaning of what is said. Synonyms in childrens speech differ in semantic nuances, emotionally expressive collaring, the sphere of stylistic use or the possibility of combining with other words. In practical-game situations of everyday speech for speakers close in meaning may be words that are not recorded in the dictionaries of synonyms. Subjectively close are the units, combined with thematic and genus-species relations, so in each case of use, you can find the most appropriate word. The synonymy of language units is the result of the whole mechanism of the child's individual knowledge of language and speech.
\end{abstract}

Keywords: word, vocabulary, synonyms, synonymous series, speech, children of senior preschool age.

\section{Вступ \\ Introduction}

Найважливіше місце у мовленнєвій діяльності кожної дитини займає словник, який виступає передумовою спілкування i пізнання, інструментом регуляції іiі мовленнєвої поведінки, засобом розвитку й виховання. Багатство словника є ознакою добре розвиненого мовлення і показником високого рівня розумового розвитку індивіда. Лексичний склад мовлення визначає активне вживання дітьми слів різних за змістом та значенням. Слова-синоніми у мовленні дітей дошкільного віку стали предметом лінгвістичного аналізу порівняно недавно, й інтерес до вивчення синоніміі 
помітно зростає, адже наявність їх у мовленні сприяє точнішому висловлюванню думки, передати своє ставлення до того, про що говориться, уникати невиправданих повторів у висловлюваннях. Вивчення синонімів (часто використовують поняття близькість значення слів) у лексиконі дітей дошкільного віку пов'язане із їх функціонуванням в індивідуальній свідомості мовців, їхньою здатністю знаходити в реальній дійсності важливі факти й ознаки на основі подібності й відмінності та смислу сказаного.

Mema cmammi - опис результатів вивчення особливостей вживання дітьми старшого дошкільного віку слів-синонімів.

\section{Методи та методики дослідження Methods and Techniques of the Research}

Для вивчення особливостей вживання дітьми старшого дошкільного віку синонімів послуговувалися такими методами: асоціативний, метод порівняння i розрізнення, лінгвостатистичний.

\section{Результати Results}

Сучасна лінгвістична наука визначає слово як феномен системно-мовний i психологічний. Слово бере участь у формуванні комунікативно-інформаційної сфери людини, допомагає оволодінню досвідом і становленню мовно-мовленнєвої особистості (Залевская, 2005). Функціонування слова в індивідуальній свідомості дитини визначається рівнем сформованості образу світу, місцем слова в іiі мовній системі та його комунікативними характеристиками. Серед різноманітності слів, які засвоює дитина помітну роль займають слова близькі за значенням або синоніми одиниці індивідуального лексикону людини (Гапченко, 2017).

Слова-синоніми за своїм спільним основним значенням об’єднуються в синонімічні ряди, що утворюють систему відтінків одного значення. У синонімічному ряді виділяється головне (стрижневе, опорне) слово - домінанта - носій основного значення, спільного для всього синонімічного ряду, стилістично нейтральне слово, найуживаніше. В словниках синонімів домінанта стоїть на першому місці: дружний злагоджений, одностайний; дружній - братерський, приятельський, приязний, товариський, дружелюбний.

Використовуючи термін близькість значення слів, мають на увазі різні аспекти семантики слова. Близькість значень слів визначається подібністю їхніх семантичних 
профілів або близькістю координат у «семантичному просторі». Однак, не для всякого мовного факту вдається знайти відповідне слово-синонім і, що взагалі останнє не може бути повністю рівнозначним домінуючому слову, бо два мовних факти ніколи не бувають абсолютно синонімічними (Osgood, Suci \& Tannenbaum, 1957). Уся психофізіологічна діяльність дорослої людини (Гапченко, 2017) грунтується на здатності знаходити в реальній дійсності важливі факти й ознаки на основі подібності й відмінності. Ця тенденція має універсальний характер і може розглядатися як психологічна реальність.

Під час вивчення синонімів у мовленні дітей враховували той факт, що вони об’єднуються в синонімічні ряди та виражають спільний сенс. Повсякденна мовна практика рясніє прикладами неуважності дітей до висловлюваного контенту, відсутнє свідоме ставлення до лексичних засобів (слів) взагалі.

Вивчаючи здатність дітей, підбирати до запропонованих слів слова близькі за значенням (синоніми) отримали наступні результати. Під час діагностичнорозвивальної гри «Назви по-іншому» визначали здатність підбирати до поданих слова-синоніми. Крім того, гра мала розвивальний характер і спрямована на зону активного розвитку дітей. Діти старшого дошкільного віку підбирали слова-синонімами (говорити - розмовляти, балакати; мама - матуся, матінка, мамуся; ліжко - ліжечко; ремонтувати - лагодити; тато - татусь, батько; вікно - віконце; котик - кошеня, кішечка; веселий - радісний; великий - величезний, здоровий; собака - песик, собаченя, цуцик). Найбільше і в той же час правильних синонімів діти підібрали до слів: мама, тато, котик. Мали труднощі зі словами: ремонтувати, вікно, великий.

Слід зазначити, що більшість опитаних (42\%) змогли назвати тільки одне слово-синонім до більшості запропонованих, наприклад, мама - мамуля, тато татуня (Назар І.); мама - мамуся, тато - татуся (Степан Г.); мама - мамка, тато - татусь (Ліза Б.); мама - матуся, тато - татко (Ілля С.); мама - мамуня, тато - папка (Вікторія Я.) та ін., притому найбільше відповідей було «мама мамуся, мама - мама - матуся» та «тато - татусь - папа, папка». Називання старшими дошкільниками більшої кількості синонімів до слів «мама, тато»: найбільше - це три слова-синоніми зафіксовано у 15\% опитаних; два слова-синоніми у 26 \% опитаних. Такі результати свідчать, про небагатий словник синонімів старших дошкільників попри використання «найрідніших» дитині слів.

Здатність дітей добирати синоніми до прикметників виявляли завдяки називання форм і кольорів предметів у діагностично-розвивальних іграх «Назви слова-ознаки» й отримали результати називання ознак: великий - величезний (Тетяна К.); великий - здоровий (Вікторія К.), великий - здоровенний (Вікторія Я.); великий - огромний (Давид М.), великий - величенький (Карина М.) та ін. У наступній 
грі з'ясовано, що в активному словнику старших дошкільників недостатньо синонімів до слова червоний - червоненький, наприклад, червоний - як помідор (Іван Д.); червоний - червонястий (Степан Г.); червоний - червоненький (Назар І.); червоний олівець (Ілля С.); червоний - автомобіль, пожежний (Вадим Г.) та ін. На відміну від попереднього завдання бачимо, що добирати синоніми до слів-ознак, особливо називання кольору викликало у дітей не поодинокі труднощі. Отримані відповіді дітей свідчать про те, що діти здебільшого не намагалися добирати слово-синонім, а називали предмет, який зустрічався у їхньому індивідуальному життєвому просторі (як помідор, олівецьь, автомобіль). Це свідчить про конкретність мислення дитини та про відсутність умінь об’єктивувати лексичну дійсність - знань про слова-ознаки.

Синоніми до слів, які називають дії людини діти намагалися підбирати, граючись у гру «Назви дію по іншому». Пропонували доповнити речення, наприклад, Наша киця (спить, дрімає, спочиває). На небі (світить, гріє, блищить, виблискує, переливається, припікає) сонечко. Біля будинку (бігав, пробігав, ходив, стрибав) собачка. Стежка (вела, простилалася, прямувала, стелилася, направлялася) прямо. Вдосвіта (кукурікав, співав, кричав) півень. Після весни (буде, прийде, настане, наступить) літо. Дане завдання стало найскладнішим. Діти шляхом повсякденної мовної практики підбирали синоніми безсистемно. Як бачимо, з прикладів: вела, простилалася, прямувала, стелилася, направлялася (стежка); світить, гріє, блищить, виблискує, переливається, припікає (сонще) та ін. діти утворюють синонімічний ряд у спосіб, який грунтується на смислових асоціаціях, такий спосіб став найбільш раціональним у підборі слів близьких у смисловому значенні запропонованих висловлювань.

\section{Висновки Conclusions}

Отже, вивчаючи синоніми в мовленні дітей старшого дошкільного віку орієнтувалися на розуміння цієї категорії слів як таких, що означають назву того самого поняття і $є$ спільними за своїм основним значенням, але можуть відрізняються смисловими відтінками, емоційно-експресивним забарвленням, сферою стилістичного вживання або можливостями поєднання 3 іншими словами. У практично-ігрових ситуаціях повсякденного мовленнєвого буття для мовців близькими за значенням можуть бути слова, не зафіксовані у словниках синонімів. Суб’єктивно близькими можуть бути одиниці, поєднані тематичними й родовидовими відношеннями, тому в кожному конкретному випадку вживання можна 
знайти найбільш відповідне слово. Синонімічність мовних одиниць $є$ результатом дії всього механізму індивідуальних знань дитини про мову і мовлення.

\section{Література References}

Белов, В.А. (2014). Типы синонимических рядов. Вопросы психолингвистики, 22, 125-137. Гапченко, О.А. (2017). Синонімія як один із механізмів організації одиниць індивідуального лексикону природного білінгва. Science and Education a New Dimension. Philology, 34(124), 31-34.

Залевская, А.А. (2005). Психолингвистические исследования. Слово. Текст: Избранные труды. Москва: Гнозис.

Караванський, С. (2000). Практичний словник синонімів украӥнської мови. Київ: Українська книга

Леонтьев, А.А. (1969). Психолингвистические единиџы и порождение речевого высказывания. Москва: Наука.

Полюга, Л.М. (2006). Словник синонімів української мови. (2-е вид.). Київ: Довіра.

Трофименко, Л.І. (2013). Теоретичні засади дослідження лексичної сторони мовлення у дошкільників в умовах нормального та порушеного онтогенезу, 4(1), 85-95.

Osgood, Ch.E., Suci G.J., \& Tannenbaum, P.H. (1957). The Measurement of Meaning. Urbana: University of Illinois Press. 346 p. 